year course of training. Martin Leake described this venture as "the boldest experiment in colonial agriculture during the present century". However, the charming and easy-going Fijians did not take kindly to the exacting task of raising sugar cane, Indian labour was introduced, and to-day most of the farms are in the hands of Indians, who now outnumber the indigenous Fijian population.

Since 1923 all the raw sugar produced in Australia passes into a pool, controlled by the Queensland Sugar Board, which is operated on its behalf by the Colonial Sugar Refining Co. The Company markets and ships the raw sugar that is surplus to home requirements and it thus has world-wide responsibilities. The home market in Austra]ia and New Zealand is supplied from its own refineries with one small exception. The disposal of the two by-products of the sugar mills, megass, the fibre from which the sugar has been extracted, and molasses, the residual liquor, has produced two major expansions of the Company's activities in recent years. The manufacture of wall boards from megass has led to the large-scale production of building materials from hard woods and asbestos, and an extensive chemical industry has been based on molasses as a raw material in a subsidiary company in partnership with the Distillers Company of Britain.

All these developments are typical of the enterprise which has characterized the Company since its early days, thanks to which it became the first major industrial organization in Australia and its original capital of $£ 150,000$ grew to $£ 14$ million. The book gives a fascinating account of its history and is of special interest in showing the place it occupies in the economic planning of the world sugar industry.

The individual cultivator of sugar, often with a small holding, is exposed to the risks of the weather and world prices. The Company has played a very active part in the national and international agreements which aim at giving reasonable stability to the industry by planned production and marketing, with a margin to allow for development and experiment. One of the most interesting chapters describes the working of the Commonwealth Sugar Agreement of 1951 and the International Sugar Agreement of 1953, showing the value of a large organization like the Colonial Sugar Refining Co. with adequate resources for research and development, and with continuity of policy based on long experience which has benefited alike the cultivator, the consumer and those engaged in this essential industry. HAROLD HARTLEY

\section{SOME MODERN ASPECTS OF ENZYME RESEARCH}

\section{Enzymes}

Units of Biological Structure and Function. Edited by Oliver H. Gaebler. (Henry Ford Hospital International Symposium.) Pp. xiv +624. (New York: Academic Press, Inc.; London : Academic Books, Ltd., 1956.) 12 dollars.

7 HIS book is a record of the formal contributions and discussion at a symposium held in Detroit in November 1955. During the past fow years there has been an exponential growth in work and interest concerning aspects of enzyme action other than the chemistry and kinetics of the reactions catalysed and the intimate chemical mechanism of the catalysis. It was to these broader fields that the symposium was devoted; the borderlands between enzyme biochemistry on one hand and cell structure, genetics and physiology on the other. The promising, and in some cases dramatic, increase in knowledge has, of course sprung to some extent from technical advances in, for example, electron microscopy, refined spectrophotometry and the induction and use of mutants of micro-organisms.

The symposium ranged over so wide a field that it is impossible to provide a scientific summary. Equally it would be invidious to select contributions for individual comment; all twenty-nine formal contributors are authorities in their respective fields. The sections on the mechanism of enzyme formation (extending to protein synthesis in general) and its genetic control were naturally based mainly on work with micro-organisms. The session on the relationship of enzymes to cell structure emphasized the potentialities of electron microscopy and cytochemistry. Contributions on cellular energy sources centred on the role of hæm compounds. Specific physiological processes considered in enzymic terms included muscular contraction, secretion and re-absorption in the kidney, vision and bioluminescence. A final session discussed the most elusive problem of allthe co-ordinated regulation of enzyme activity.

The book should prove a most valuable and stimulating guide both to research workers and advanced students. The former may be provoked to considering their own problems more from the point of view of the living intact organism; the latter will also find the symposium gives a novel cross-section of biochemistry and a new appreciation of the real outstanding problems.

Verbatim reports of the general discussion are also given. Except in so far as items of factual information are concerned, the reviewer does not find this so successful. It is not possible to transfer to the printed page the atmosphere and spirit of the conference room; a commentary by an informed reporter might have been more effective.

\section{D. Woons}

\section{HIGH-VOLTAGE TRANSMISSION SYSTEMS}

\section{A.C. Switchgear}

By Dr. J. R. Mortlock. Vol. 1 : A Survey of Requirements. (Advanced Engineering Textbooks.) Pp. $\mathrm{xi}+387$. (London: Chapman and Hall, Ltd., 1956.) 50s. net.

Neutral Grounding in High-Voltage Transmission By Dr. R. Willheim and M. Waters. Pp. xviii +669 . (Amsterdam : Elsevier Publishing Company; Lon. don: Cleaver-Hume Press, Ltd., 1956.) $90 s$.

7 HESE books discuss important aspects of highvoltage transmission systems; the switchgear controlling the system, and the method adopted to earth the neutral point.

Dr. Mortlock's book is the first volume of two on a.c. switchgear. It is intended to give guidance to power system engineers on the problems associated with the determination of switchgear ratings. The second volume will deal with basic design prineiples. 